CESIS Electronic Working Paper Series

Paper No. 293

\title{
The Impact of R\&D Activities on Exports of German Business Services Enterprises: First evidence from a continuous treatment approach.
}

\author{
Alexander Vogel \\ Joachim Wagner
}

December 2012 


\title{
The Impact of R\&D Activities on Exports of German Business Services Enterprises: First evidence from a continuous treatment approach*
}

\author{
Alexander Vogel and Joachim Wagner \\ Leuphana University Lueneburg; Leuphana University Lueneburg and CESIS, Stockholm \\ [alexander.vogel@leuphana.de; wagner@leuphana.de]
}

\begin{abstract}
This study uses newly available representative data from German business services firms and a continuous treatment approach based on the generalized propensity score to test for a causal effect of $R \& D$ activities (measured by the share of engineers and natural scientists in all employees) on the share of exports in total sales. We find evidence for a positive and statistically significant but small causal effect. This result is in line with the (non-causal) results reported in Vogel and Wagner (2012) based on regression models with and without control for unobserved time-invariant firm characteristics. The bottom line, then, is that R\&D activity does matter for success of German business services firms on export markets - but not much.
\end{abstract}

Keywords: Innovation, export, business services, Germany JEL classification: F14

* This paper is part of the project KombiFiD - Kombinierte Firmendaten für Deutschland that is financially supported by the German Ministry for Education and Research (BMBF). It is a joint project of the Institute of Economics of Leuphana University Lueneburg, the research data centres of the German Federal Statistical Office and the statistical offices of the German federal states, the Institute of Employment Research of the Federal Employment Agency and the research department of the German Central Bank. While members of the KombiFiD-team from all institutions contributed to the construction of the data set used in this paper we alone are responsible for the results presented here and the conclusions drawn. 


\section{Motivation}

International trade in services becomes more and more important for Germany that is one of the leading actors on the world market for services and that was the second largest exporter of commercial services after the United States in 2010 (World Trade Organization 2011, Appendix Table 2). Reliable empirical evidence on the characteristics of successful German exporters in services, however, is scarce, not least because comprehensive representative longitudinal data for services firms became available only recently (see Vogel and Wagner (2012) for a survey of empirical studies for Germany).

A case in point is the role played by innovation activities for exports. Information about product or process innovations and about employees in research and development $(R \& D)$ or the amount spent for $R \& D$ activities is not available from the German business services statistics panel (described in detail in Vogel (2009)), and it is only rarely used in empirical studies on services exports based on data for other countries (summarized in Vogel and Wagner (2012)). For a large sample of firms from business services industries in Germany, however, information on the share of employees in a firm that are engineers or natural scientists has been matched recently with the firm level information available in the German business services statistics panel. Using the share of engineers and natural scientists as a proxy variable for the intensity of R\&D activities of a firm Vogel and Wagner (2012) showed that export intensity and R\&D intensity of a firm are positively correlated. Furthermore, they report that this correlation is still found when unobserved firm heterogeneity is controlled for by including fixed-effects in a regression model that is estimated with firm panel data. These empirical results, however, are correlations and do not indicate the direction of causality between R\&D activity and exports. While Vogel and Wagner (2012) test for a selection effect of more R\&D intensive 
firms into export activities (and document weak evidence in favour of such an effect) they do not test for a causal effect of the amount of R\&D activities on the share of exports in total sales.

This paper contributes to the literature on services exports and R\&D by using for the first time a continuous treatment approach based on the generalized propensity score to test for a causal effect of R\&D activities (measured by the share of engineers and natural scientists in all employees) on the share of exports in total sales. To anticipate our most important result we find evidence for a positive and statistically significant but small causal effect.

The rest of the paper is organized as follows: Section 2 describes the new data set used and presents some descriptive evidence on services exports and R\&D activity. Section 3 discusses the approach based on the generalized propensity score to test for a causal effect of R\&D activities on the share of exports in total sales and reports the results of our empirical investigation. Section 4 concludes.

\section{Data and descriptive evidence}

The data used in this study are taken from two sources. The first source is the German business services statistics panel (described in detail in Vogel (2009)). This data set includes information on exports of firms and a number of other firm characteristics used as control variables (that are described in detail in section 3).

The German business services statistics panel has no information on either the share of employees engaged in research and development (R\&D), or on the amount of money spent on $R \& D$ activities, or on the introduction of innovative services. Therefore, a second source of data is used, the Establishment History Panel (Betriebs-Historik-Panel) described in detail in Spengler (2008). Details aside, this data set is built from individual level information for employees covered by social 
security and it is a data set with detailed information about the characteristics of the employees in each enterprise in a year. From these data we do not have any direct information on the number of employees working in R\&D. However, information on the composition of the workforce includes, among others, the number of engineers and natural scientists in the firm. These highly qualified employees can be expected to work on the development of innovative solutions that will eventually lead to improved or completely new ways to perform business services. Therefore, the share of engineers and natural scientists in all employees can be viewed as a suitable measure for the R\&D intensity and the innovativeness of an enterprise.

Data from both sources were combined in the project KombiFiD (an acronym for combined firm data for Germany) for the years 2003 to 2006. Due to the fact that the German business services statistics do not provide information about the export activities of small firms, only firms with an annual sum of turnover and other operational income greater than or equal to $€ 250,000$ are considered for the analyses. Furthermore, due to the very small number of firms located in the former communist East Germany the analysis is limited to firms from West Germany. The data are confidential but not exclusive; they can be used for empirical investigations inside the research data centres of the statistical offices in Germany (see www.kombifid.de for details). ${ }^{1}$

Table 1 shows that in our sample only one in four business services firms is an exporter and only one in five firms employs engineers and natural scientists. Many exporting firms export only a small share of all services produced, and many firms

\footnotetext{
${ }^{1}$ Some firms reported extremely high or low values of some variables used. To avoid bias of the econometric estimations by outliers, firms that belong to the 1st or 99th percentile of the wage or value added distribution or to the 99th percentile of the number of persons employed, investment or purchased goods and services for resale distribution are excluded from all computations. Results for the full sample are available from the first author on request.
} 
with $R \& D$ activities have only a small share of engineers and natural scientists. Firms with export intensity or an R\&D intensity of more than 50 percent are rare. Note that Vogel and Wagner (2012) report that the average share of engineers and natural scientists in all employees is 3.8 percent in non-exporting firms compared to 6.5 percent in exporting firms - a large and statistically highly significant difference in $R \& D$ intensity.

[Table 1 near here]

\section{Causal effect of R\&D activities on exports}

In this section we examine whether there is a causal effect of a firm's R\&D activity on its exports. Unfortunately, we cannot evaluate post-entry differences in exports between R\&D starters and non-starters due to the time frame of the data used and the small number of firms that start to be active in R\&D. Nonetheless, the question of whether R\&D activities have a positive effect on exports is crucial for our analysis.

The hypothesis of a positive causal effect of R\&D activity on exports is tested using the generalised propensity score (GPS) methodology developed by Imbens (2000) and Hirano and Imbens (2004). The GPS methodology was introduced to the literature on the micro-econometrics of international firm activities by Fryges (2009) and applied by Fryges and Wagner $(2008,2010)$ and by Vogel and Wagner $(2010)$ who estimated the relationship between exports and labour productivity growth, and the relationship between exports and profitability using samples of German firms from manufacturing industries and business services.

The GPS methodology has a number of advantages compared to other econometric techniques. First, the GPS method allows for continuous treatment, i.e., different levels of the firms' R\&D activities, proxied by different shares of engineers 
and natural scientists in this paper. In this way, we are able to determine the causal relationship between the export-sales ratio and the level of R\&D activity (the treatment) at each value of firms' $R \& D$ intensity in the interval from zero to one. Thus, the second important advantage of the GPS method is that it enables us to identify the entire function of the export-sales ratio over all possible values of the continuous treatment variable. Thirdly, the continuous treatment approach allows us to analyse whether there is a level of the R\&D intensity at which exports are maximised (or minimised) or whether the relationship between the R\&D intensity and the exportsales ratio exhibits turning points or discontinuities (cf. Flores 2004). A detailed description of the GPS methodology is presented in Fryges and Wagner (2010, appendix A.1).

Using the GPS methodology, we do not compare R\&D starters versus nonstarters. R\&D starters that have hired engineers or natural scientists during the previous year generally show a very small level of $R \& D$ activity. Thus, restricting the analysis to R\&D starters precludes a reliable estimation of the causal effect of medium-sized or large levels of R\&D activity on exports. Our causal analysis in this section therefore includes $R \& D$ starters as well as firms that were active in $R \& D$ for decades. We estimate the causal effect of the share of employees active in R\&D measured in period $t$ on the share of exports in total sales in $t+1$. In this way, the GPS method is an appropriate econometric technique that provides an analysis of the causal effect of R\&D on exports despite the fact that, due to data restrictions, we cannot follow cohorts of R\&D starters over the next years after starting R\&D activities.

Hirano and Imbens (2004) suggest a three-stage approach to implement the GPS method. In the first stage, the conditional distribution of the treatment variable given the covariates is estimated. In our case, the distribution of the treatment 
variable, i.e. the share of engineers and natural scientists in all employees, is highly skewed. In particular, it has many limit observations at the value zero, representing firms without any R\&D employees. The latter group of firms decided that their optimal volume of R\&D activity was zero. Following the approach used in Wagner (2001, 2003) to estimate the export intensity of firms (where a large fraction of firms reported no exports at all), we apply the fractional logit model developed by Papke and Wooldridge (1996) to estimate the R\&D intensity of the firms in our sample. ${ }^{2}$ In the second stage of the GPS method the conditional expectation of outcome (share of exports in total sales in our case) is modelled as a function of the treatment and the (estimated) generalised propensity score. In the last stage, we estimate a doseresponse function that depicts the conditional expectation of export intensity given the continuous treatment (R\&D intensity) and the GPS, evaluated at any level of the continuous treatment variable in the interval from zero to one.

As stated above, we first estimate the conditional distribution of the share of engineers and natural scientists in all employees given the covariates, applying the fractional logit model. We admit that the specification of the empirical model used is not based on a coherent theory of the optimal share of employees active in R\&D in a firm. The specification is data driven. Given that the fractional logit model is estimated in order to calculate the generalised propensity score (GPS) that in turn is used to remove the bias associated with differences in covariates between treated firms (with R\&D activities) and non-treated firms (without R\&D activities) we include information on all firm characteristics from our data set that might be expected to be related to the intensity of $R \& D$. That said, the exogenous covariates of the fractional logit model include firm size (measured as the number of employees and its squared

\footnotetext{
2 Hirano and Imbens (2004) use a normal distribution for (the logarithm of) the treatment variable of their model. However, they emphasise that more general models may be considered.
} 
value), labour productivity (value added per employee), the wages per employee (to proxy human capital intensity), the share of part-time employees ${ }^{3}$, and the share of purchased goods and services for resale on total turnover. Furthermore, the set of covariates contains gross investment per person employed, dummy variables for firms with 1 or 2 subsidiaries and firms with 3 or more subsidiaries, 2-digit industry dummy variables and dummy variables for different legal status. The results of the fractional logit model are documented in Table 2. Given that our aim here is not to test theoretical hypotheses on the determinants of the R\&D intensity of a firm we do not discuss these results in detail.

The fractional logit model is estimated in order to calculate the generalised propensity score (GPS). As Imbens (2000) shows, adjusting for the GPS removes all the bias associated with differences in covariates between treated firms (with R\&D activities) and non-treated firms (without R\&D activites). Thus, in the second stage of Hirano and Imbens' GPS methodology the conditional expectation of the share of exports in total sales in year $t+1$ (outcome) is modelled as a function of the R\&D intensity in year $\mathrm{t}$ (treatment) and the estimated generalised propensity score. To approximate the predictor for the conditional expectation of the outcome we use a polynomial function with a cubic term of the treatment variable and a cubic term of the estimated GPS. In the last stage of the GPS method, the average expected outcome at each value of R\&D intensity (treatment level) in the interval from zero to one is estimated, using the regression coefficients from the second stage of the GPS method. Thus we obtain an estimate of the entire dose-response function that shows the average potential outcome at each dose of the treatment and how average

\footnotetext{
3 The information on the number of employees is not stated in full-time equivalent units. This difference has to be considered while interpreting the coefficients of the number of employees, the average wage, and the labour productivity variable, because the values of these variables are underestimated in the case of enterprises with a high share of part-time employed persons. To minimize this problem, the share of part-time employed persons is included in the estimation as a control variable.
} 
responses vary along the interval from zero to one. The confidence intervals of the dose-response functions in this paper are determined via bootstrapping. ${ }^{4}$

The dose-response function that represents the expected export-sales ratio conditional on the share of engineers and natural scientists and the GPS is depicted in Figure 1. Due to the fact that only a small number of firms in the data set have an $R \& D$ intensity that is greater than 50 percent (see Table 1), we restrict our interpretation on the $R \& D$ intensity interval from zero to 50 percent.

In the interval from zero to 50 percent of engineers and natural scientists the dose response function is highly similar in all three years. It tends to be flat over a large part of this interval. The causal impact is positive throughout, and statistically significantly different from zero according to the simulated confidence bounds at the 95 percent level in 2005 and over a wide span up to about 35 percent to 40 percent of engineers and natural scientists in the two other years. This impact increases with the intensity of R\&D at the very beginning of the distribution of the treatment intensity, clearly indicating that some $R \& D$ activity leads to an increase of the exportsales ratio compared to a situation without $R \& D$ activity. The positive causal impact, however, is small - the point estimate of the maximum is below ten percentage points.

\section{Conclusion}

This study uses newly available representative data from German business services firms and a continuous treatment approach based on the generalized propensity score to test for a causal effect of R\&D activities (measured by the share of engineers and natural scientists) on the share of exports in total sales. We find

\footnotetext{
${ }^{4}$ Computations were done using Stata 10 and the Stata package for the estimation of dose-response functions (see Bia and Mattei (2008)) that was adjusted by the authors concerning the use of the fractional logit model in the first step of the GPS method.
} 
evidence for a positive and statistically significant but small causal effect. These results are in line with the (non-causal) results reported in Vogel and Wagner (2012) based on regression models with and without control for unobserved time-invariant firm characteristics. The bottom line, then, is that R\&D activity does matter for success of business services firms on export markets - but not much.

Given that Germany is one of the leading actors on the world market for both goods and services, the evidence provided here is interesting on its own. Furthermore, it can serve as a benchmark for future studies using comparable data for firms from services industries in other countries.

\section{References}

Bia, Michela and Mattei, Alessandra (2008): "A Stata package for the estimation of the dose-response function through adjustment for the generalized propensity score", The Stata Journal 8, $354-373$.

Flores, Carlos A. (2004): "Estimation of Dose-Response Functions and Optimal Doses with a Continuous Treatment", Job Market Paper, University of California, Berkeley.

Fryges, Helmut (2009): "The Export-Growth Relationship: Estimating a DoseResponse Function", Applied Economics Letters 16, 1855-1859.

Fryges, Helmut and Wagner, Joachim (2008): "Exports and Productivity Growth First Evidence from a Continuous Treatment Approach", Review of World Economics / Weltwirtschaftliches Archiv 144, 695-722.

Fryges, Helmut and Wagner, Joachim (2010): "Exports and Profitability - First Evidence for German Manufacturing Firms", The World Economy 33, 399-423. 
Hirano, Keisuke and Imbens, Guido W. (2004): "The Propensity Score with Continuous Treatments", in: Gelman, Andrew / Meng, Xiao-Li (eds.): Applied Bayesian Modeling and Causal Inference from Incomplete-Data Perspectives, Chichester: Wiley, 73-84.

Imbens, Guido W. (2000): "The Role of the Propensity Score in Estimating DoseResponse Functions", Biometrika 87, 706-710.

Papke, Leslie E. and Wooldridge, Jeffrey Marc (1996): "Econometric Methods for Fractional Response Variables with an Application to 401(K) Plan Participation Rates", Journal of Applied Econometrics 11, 619-632.

Spengler, Anja (2008): "The Establishment History Panel", Schmollers Jahrbuch / Journal of Applied Social Science Studies 128, 501-509.

Vogel, Alexander (2009): “The German Business Services Statistics Panel 2003 2007", Schmollers Jahrbuch / Journal of Applied Social Science Studies 129, $515-522$.

Vogel, Alexander and Wagner, Joachim (2010): "Exports and Profitability - First Evidence for German Business Services Enterprises", Applied Economics Quarterly 56, 7-30.

Vogel, Alexander and Wagner, Joachim (2012): "Innovation and Exports of German Business Services Enterprises: First Evidence from a new type of data", University of Lüneburg Working Paper Series in Economics No. 246, August.

Wagner, Joachim (2001): "A Note on the Firm Size - Export Relationship", Small Business Economics 17, 229-237.

Wagner, Joachim (2003): "Unobserved Firm Heterogeneity and the Size-Exports Nexus: Evidence from German Panel Data", Review of World Economics 139, 161-172. 
World Trade Organization (2011): "World Trade Report 2011: The WTO and preferential trade agreements: From co-existence to coherence." Generva: WTO Publications. 


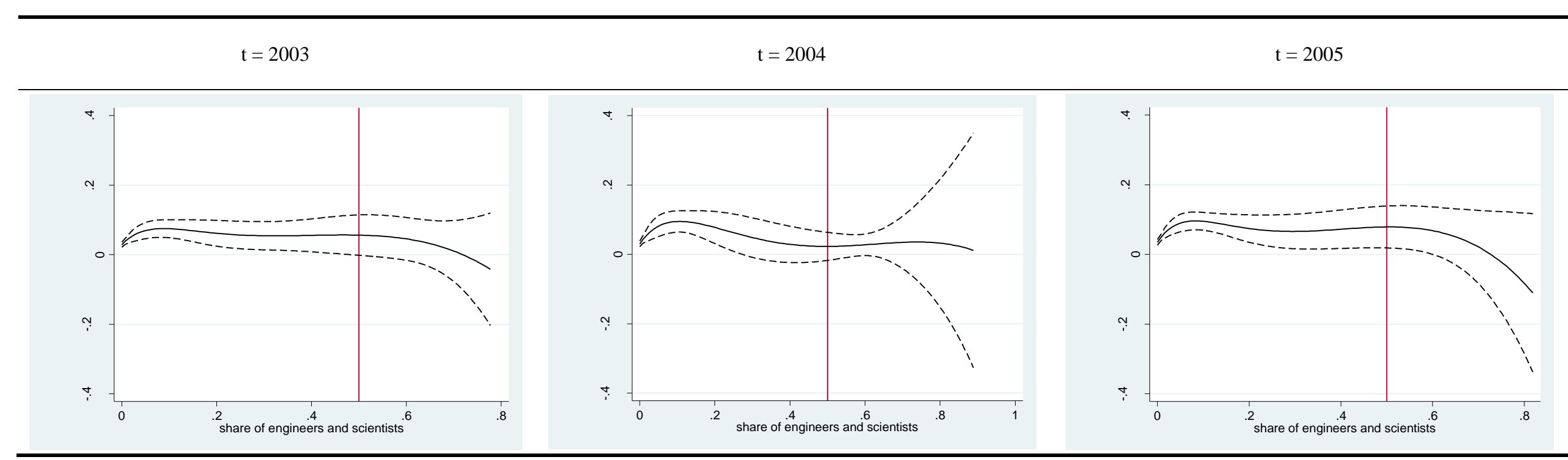

Note:

The solid lines indicate the estimated conditional expectation of the export intensity given the share of engineers and scientists in $t$ and the estimated generalised propensity score (GPS). The dotted lines indicate the simulated confidence bounds at $95 \%$ level (based on bootstrapping with 100 replications). Only enterprises with a sum of turnover and other

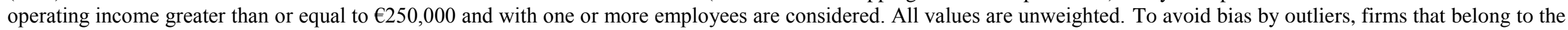
1st or 99th percentile of the wage or value added distribution or to the 99th percentile of the number of persons employed, investment or purchased goods and services for resale distribution are excluded from all computations.

Source:

Research Data Centres of the Federal Statistical Office and the statistical offices of the Länder and Research Data Centre of the German Federal Employment Agency at the Institute for Employment Research, KombiFiD dataset 2003-2006, Author's own calculations. 
Table 1: Export and R\&D activities of business services enterprises 2003 - 2005

\begin{tabular}{|c|c|c|c|c|c|c|}
\hline & \multicolumn{2}{|c|}{2003} & \multicolumn{2}{|c|}{2004} & \multicolumn{2}{|c|}{2005} \\
\hline & Number of firms & $\begin{array}{c}\text { Share of firms in all } \\
\text { firms in } \%\end{array}$ & Number of firms & $\begin{array}{c}\text { Share of firms in all } \\
\text { firms in } \%\end{array}$ & Number of firms & $\begin{array}{l}\text { Share of firms in all } \\
\text { firms in } \%\end{array}$ \\
\hline \multicolumn{7}{|l|}{ Export intensity } \\
\hline $0 \%$ & 1,443 & 76.6 & 1,367 & 74.6 & 1,352 & 74.4 \\
\hline$>0 \%$ and $<5 \%$ & 237 & 12.6 & 252 & 13.8 & 232 & 12.8 \\
\hline$\geq 5 \%$ and $<10 \%$ & 60 & 3.2 & 65 & 3.6 & 62 & 3.4 \\
\hline$\geq 10 \%$ and $<25 \%$ & 71 & 3.8 & 67 & 3.7 & 85 & 4.7 \\
\hline$\geq 25 \%$ and $<50 \%$ & 46 & 2.4 & 45 & 2.5 & 52 & 2.9 \\
\hline$\geq 50 \%$ & 26 & 1.4 & 36 & 2.0 & 35 & 1.9 \\
\hline \multicolumn{7}{|c|}{ Share of engineers and scientists } \\
\hline $0 \%$ & 1,495 & 79.4 & 1,446 & 78.9 & 1,426 & 78.4 \\
\hline$>0 \%$ and $<5 \%$ & 91 & 4.8 & 95 & 5.2 & 96 & 5.3 \\
\hline$\geq 5 \%$ and $<10 \%$ & 53 & 2.8 & 54 & 3.0 & 61 & 3.4 \\
\hline$\geq 10 \%$ and $<25 \%$ & 98 & 5.2 & 102 & 5.6 & 89 & 4.9 \\
\hline$\geq 25 \%$ and $<50 \%$ & 107 & 5.7 & 97 & 5.3 & 101 & 5.6 \\
\hline$\geq 50 \%$ & 39 & 2.1 & 38 & 2.1 & 45 & 2.5 \\
\hline
\end{tabular}

Note:

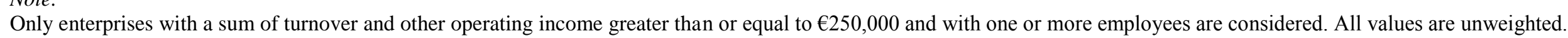
To avoid bias by outliers, firms that belong to the 1st or 99th percentile of the wage or value added distribution or to the 99th percentile of the number of persons employed, investment or purchased goods and services for resale distribution are excluded from all computations.

Source:

Research Data Centres of the Federal Statistical Office and the statistical offices of the Länder and Research Data Centre of the German Federal Employment Agency at the Institute for Employment Research, KombiFiD dataset 2003-2006, Author's own calculations. 
Table 2: Determinants of the share of engineers and scientists in $t$ (endogenous variable) - results of fractional logit models

\begin{tabular}{|c|c|c|c|c|}
\hline & & $t=2003$ & $t=2004$ & $t=2005$ \\
\hline Export intensity & $\begin{array}{l}\beta \\
p \text {-value }\end{array}$ & $\begin{array}{r}0.9162382 \\
0.042\end{array}$ & $\begin{array}{r}1.1145730 \\
0.002\end{array}$ & $\begin{array}{r}0.7231060 \\
0.029\end{array}$ \\
\hline Number of employees & $\begin{array}{l}\beta \\
\mathrm{p} \text {-value }\end{array}$ & $\begin{array}{r}-0.0021487 \\
0.047\end{array}$ & $\begin{array}{r}-0.0017431 \\
0.160\end{array}$ & $\begin{array}{r}-0.0019284 \\
0.080\end{array}$ \\
\hline Number of employees (squared) & $\begin{array}{l}\beta \\
\mathrm{p} \text {-value }\end{array}$ & $\begin{array}{r}0.0000009 \\
0.247\end{array}$ & $\begin{array}{r}0.0000001 \\
0.920\end{array}$ & $\begin{array}{r}0.0000009 \\
0.328\end{array}$ \\
\hline $\begin{array}{l}\text { Labour productivity (value added } \\
\text { per employee) }\end{array}$ & $\begin{array}{l}\beta \\
\mathrm{p} \text {-value }\end{array}$ & $\begin{array}{r}0.0000009 \\
0.503\end{array}$ & $\begin{array}{r}0.0000005 \\
0.709\end{array}$ & $\begin{array}{r}0.0000004 \\
0.803\end{array}$ \\
\hline Wage per employee & $\begin{array}{l}\beta \\
p \text {-value }\end{array}$ & $\begin{array}{r}0.0000164 \\
0.000\end{array}$ & $\begin{array}{r}0.0000142 \\
0.000\end{array}$ & $\begin{array}{r}0.0000125 \\
0.000\end{array}$ \\
\hline Part-time workers (in percent) & $\begin{array}{l}\beta \\
\mathrm{p} \text {-value }\end{array}$ & $\begin{array}{r}-0.0110519 \\
0.005\end{array}$ & $\begin{array}{r}-0.0114953 \\
0.007\end{array}$ & $\begin{array}{r}-0.0165769 \\
0.000\end{array}$ \\
\hline $\begin{array}{l}\text { Goods and services for } \\
\text { resale (in percent of turnover ) }\end{array}$ & $\begin{array}{l}\beta \\
\mathrm{p} \text {-value }\end{array}$ & $\begin{array}{r}-0.0009484 \\
0.814\end{array}$ & $\begin{array}{r}-0.0016137 \\
0.661\end{array}$ & $\begin{array}{r}-0.0020463 \\
0.623\end{array}$ \\
\hline Investment & $\begin{array}{l}\beta \\
\mathrm{p} \text {-value }\end{array}$ & $\begin{array}{r}-0.0000004 \\
0.955\end{array}$ & $\begin{array}{r}0.0000080 \\
0.123\end{array}$ & $\begin{array}{r}-0.0000061 \\
0.385\end{array}$ \\
\hline $\begin{array}{l}1 \text { or } 2 \text { subsidiaries } \\
\text { (Dummy) }\end{array}$ & $\begin{array}{l}\beta \\
\mathrm{p} \text {-value }\end{array}$ & $\begin{array}{r}0.5823165 \\
0.001\end{array}$ & $\begin{array}{r}0.2235632 \\
0.224\end{array}$ & $\begin{array}{r}0.2746283 \\
0.125\end{array}$ \\
\hline $\begin{array}{l}3 \text { and more subsidiaries } \\
\text { (Dummy) }\end{array}$ & $\begin{array}{l}\beta \\
\mathrm{p} \text {-value }\end{array}$ & $\begin{array}{r}0.5810834 \\
0.017\end{array}$ & $\begin{array}{r}0.4928244 \\
0.046\end{array}$ & $\begin{array}{r}0.4403414 \\
0.090\end{array}$ \\
\hline $\begin{array}{l}\text { Private company } \\
\text { (Dummy) }\end{array}$ & $\begin{array}{l}\beta \\
\mathrm{p} \text {-value }\end{array}$ & $\begin{array}{r}-0.1066921 \\
0.698\end{array}$ & $\begin{array}{r}-0.1796759 \\
0.532\end{array}$ & $\begin{array}{r}-0.2481316 \\
0.380\end{array}$ \\
\hline $\begin{array}{l}\text { Public limited company } \\
\text { (Dummy) }\end{array}$ & $\begin{array}{l}\beta \\
\mathrm{p} \text {-value }\end{array}$ & $\begin{array}{r}-0.0750490 \\
0.773\end{array}$ & $\begin{array}{r}-0.1241483 \\
0.648\end{array}$ & $\begin{array}{r}-0.2565275 \\
0.348\end{array}$ \\
\hline $\begin{array}{l}\text { Other Legal status } \\
\text { (Dummy) }\end{array}$ & $\begin{array}{l}\beta \\
\mathrm{p} \text {-value }\end{array}$ & $\begin{array}{r}0.1925431 \\
0.599\end{array}$ & $\begin{array}{r}0.2494741 \\
0.508\end{array}$ & $\begin{array}{r}-0.0432837 \\
0.908\end{array}$ \\
\hline $\begin{array}{l}\text { NACE Code } 72 \text { (computers and } \\
\text { related activities) (Dummy) }\end{array}$ & $\begin{array}{l}\beta \\
\mathrm{p} \text {-value }\end{array}$ & $\begin{array}{r}-2.1690420 \\
0.000\end{array}$ & $\begin{array}{r}1.7792960 \\
0.000\end{array}$ & $\begin{array}{r}-2.3074880 \\
0.000\end{array}$ \\
\hline $\begin{array}{l}\text { NACE Code } 74 \text { (other business } \\
\text { services activities) (Dummy) }\end{array}$ & $\begin{array}{l}\beta \\
\mathrm{p} \text {-value }\end{array}$ & $\begin{array}{r}-1.2766600 \\
0.000\end{array}$ & $\begin{array}{r}0.8089547 \\
0.000\end{array}$ & $\begin{array}{r}-1.4125020 \\
0.000\end{array}$ \\
\hline Number of observations & & 1,883 & 1,832 & 1,818 \\
\hline
\end{tabular}

Note:

Presented are the coefficients and the p-values of fractional probit regressions of the share of engineers and scientists on several regressors. Only enterprises with a sum of turnover and other operating income greater than or equal to $€ 250,000$ and with one or more employees are considered. All values are unweighted. To avoid bias by outliers, firms that belong to the 1st or 99th percentile of the wage or value added distribution or to the 99th percentile of the number of persons employed, investment or purchased goods and services for resale distribution are excluded from all computations. Reference groups of the dummy variables: no subsidiary in Germany, sole proprietor, NACE Code 73 (research and development). 
Source:

Research Data Centres of the Federal Statistical Office and the statistical offices of the Länder and Research Data Centre of the German Federal Employment Agency at the Institute for Employment Research, KombiFiD dataset 2003-2006, Author's own calculations. 